\title{
EKSTRAKSI PIGMEN ANTOSIANIN DARI KULIT BUAH NAGA MERAH (Hylocereus polyrhizus)
}

\author{
Lidya Simanjuntak, Chairina Sinaga, Fatimah \\ Departemen Teknik Kimia, Fakultas Teknik, Universitas Sumatera Utara, \\ Jl. Almamater Kampus USU, Medan 20155, Indonesia \\ Email : dya_mel@yahoo.com
}

\begin{abstract}
Abstrak
Ekstraksi pigmen antosianin dari kulit buah naga merah (Hylocereus polyrhizus) telah selesai dilakukan. Pigmen antosianin dari kulit buah naga merah (Hylocereus polyrhizus) dapat dijadikan sebagai alternatif pengganti pewarna sintesis. Ekstraksi zat warna antosianin pada penelitian ini dilakukan dengan metode ekstraksi maserasi. Penelitian ini menggunakan tiga variabel bebas yaitu jenis pelarut (aquades, etanol 95\%, etil asetat dan asam sitrat 10\%), rasio pelarut $(1: 2,1: 3$ dan 1:4,) dan lama ekstraksi (1 hari, 2 hari dan 3 hari). Penelitian ini bertujuan untuk mengetahui jenis pelarut, rasio pelarut dan waktu ekstraksi yang baik. digunakan. Parameter dalam penelitian ini adalah nilai $\mathrm{pH}$, nilai absorbansi dan rendemen pigmen antosianin. Hasil percobaan diperoleh bahwa kadar pigmen antosianin dari kulit buah naga merah dengan campuran pelarut aquades ditambah asam sitrat $10 \%$, menghasilkan kadar rendemen pigmen antosianin tertinggi 62,68\% pada nilai $\mathrm{pH} 2$ dan lama ekstraksi 3 hari.
\end{abstract}

Kata kunci : antosianin, ekstraksi, kulit buah naga merah, pigmen

\begin{abstract}
Extraction of anthocyanin pigments from the red pitaya's peel (Hylocereus polyrhizus) has been done. Anthocyanin pigment from the red pitaya's peel (Hylocereus polyrhizus) can be used as an alternative for sinthetys dye. Extraction of anthocyanin pigments in this experiment is using maceration method. There are three independent variables used in this experiment, they are the type of solvent (distilled water, 95\% ethanol, ethyl acetate and 10\% citric acid), solvent ratios (1:2, 1:3 and 1:4,) and the time of extraction process $(1,2$ and 3 days). This experiment aims to determine the right type of solvent, better solvent ratio and better extraction time that used to get anthocyanin pigments from red pitaya's peel. The measurements in this experiment are based on the $\mathrm{pH}$ value, the absorbance value and anthocyanin pigment yield. The experimental results shows that the levels of anthocyanin pigments of red pitaya's peel dissolved in a solvent mixture of distilled water plus $10 \%$ citric acid produce the highest level of anthocyanin pigment yield is $62.68 \%$ at $\mathrm{pH} 2$ and the extraction time are 3 days.
\end{abstract}

Keywords : anthocyanin, extraction, pitaya's peel, pigment

\section{Pendahuluan}

Maraknya penggunaan pewarna makanan yang dilarang terutama pada jajanan pasar membuat konsumen merasa khawatir terhadap aspek keamanan pangan, oleh sebab itu perlu adanya alternatif penggunaan pewarna pada makanan. Untuk menggantikan pewarna-pewarna sintetis yang sudah tidak diizinkan lagi, sebaiknya digunakan pewarna alami atau yang diizinkan. Pewarna alami seperti buah bit merah, daun suji, daun pandan, dan kunyit merupakan salah satu alternatif pengganti pewarna untuk bahan makanan. Pigmen lain yang dapat diekstrak dari sumber bahan alami adalah antosianin dari kulit buah naga Hylocereus polyrhizus [5].
Antosianin merupakan kelompok pigmen yang berwarna merah sampai biru yang tersebar luas pada tanaman. Antosianin tergolong pigmen yang disebut flavonoid [2]. Senyawa golongan flavonoid termasuk senyawa polar dan dapat diekstraksi dengan pelarut yang bersifat polar pula. Beberapa pelarut yang bersifat polar diantaranya etanol, air dan etil asetat. Kondisi asam akan mempengaruhi hasil ekstraksi. Keadaan yang semakin asam apalagi mendekati $\mathrm{pH} 1$ akan menyebabkan semakin banyaknya pigmen antosianin berada dalam bentuk kation flavilium atau oksonium yang berwarna dan pengukuran absorbansi akan menunjukkan jumlah antosianin yang semakin besar [4]. Disamping itu keadaan yang semakin asam menyebabkan semakin 
banyak dinding sel vakuola yang pecah sehingga pigmen antosianin semakin banyak yang terekstrak [6].

Telah banyak dilakukan penelitian mengenai ekstraksi pigmen antosianin dari kulit buah, seperti yang dilakukan Anis (2002) mengenai pengolahan kulit buah naga super merah, dengan menggunakan pelarut air dan asam sitrat menghasilkan rendemen terbesar yaitu $10,20 \%$ pada massa simpan 4 hari dengan perbandingan pelarut air dan asam sitrat sebesar 9:1 dan $\mathrm{pH}$ 1,91 [1]. Oleh karena itu, pada penelitian ini akan dikaji pengaruh penggunaan pelarut ditambah asam sitrat, rasio pelarut dan lama ekstraksi yang tepat untuk mendapatkan nilai rendemen yang tinggi.

\section{Teori}

Warna mempunyai arti dan peranan yang sangat penting pada komoditas pangan dan hasil pertanian lainnya. Peranan itu sangat nyata pada 3 hal yaitu daya tarik, tanda pengenal dan atribut mutu. Suatu bahan yang dinilai bergizi, enak dan teksturnya sangat baik tidak akan dimakan apabila memiliki warna yang tidak sedap dipandang atau memberi kesan telah menyimpang dari warna yang seharusnya [7].

Buah naga merah memiliki warna merah yang sangat menarik yang disebut antosianin. Antosianin merupakan pewarna yang paling penting dan paling banyak tersebar luas dalam tumbuhan. Pigmen yang berwarna kuat dan larut dalam air ini adalah penyebab hampir semua warna merah jambu, merah marak, merah senduduk, ungu, dan biru dalam bunga, daun, dan buah pada tumbuhan tingggi [6].<smiles></smiles>

Gambar 1. Struktur antosianin [3]

Gambar 1 merupakan struktur antosianin yaitu suatu turunan struktur aromatik tunggal dengan penambahan atau pengurangan gugus hidroksil atau dengan metilasi atau glikosida [2]. Terdapat enam antosianin yang umum. Antosianin yang paling umum ialah sianidin, pelargonidin delfinidin, peonidin, petunidin, dan malvirin [5]. Antosianin tergolong pigmen yang disebut flavonoid yang pada umumnya larut dalam air. Flavonoid mengandung dua cincin benzen yang dihubungkan oleh tiga atom karbon [6].

\section{Metodelogi Penelitian}

Ekstraksi pigmen antosianin dari kulit buah naga merah dilakukan dengan menggunakan ekstraksi maserasi. Variabel yang digunakan adalah jenis pelarut yaitu 1. campuran aquades ditambah asam sitrat $10 \%$; 2. Campuran etanol ditambah asam sitrat $10 \%$; 3. Campuran etil asetat ditambah asam sitrat $10 \%$. Rasio perbandingan pelarut (1:2, 1:4 dan 1:6). Lama ekstraksi (1, 2 dan 3 hari). Parameter uji dalam penelitian ini adalah nilai $\mathrm{pH}$, nilai absorbansi dan rendemen antosianin. Nilai $\mathrm{pH}$ diukur dengan menggunakan $\mathrm{pH}$ meter poket. Nilai absorbansi diukur dengan menggunakan Spektrofotometri UV-Visible (UV-1800 Shimadzu) pada panjang gelombang 500 $550 \mathrm{~nm}$. Dalam penelitian ini, Spektrofotometri UV-Visible digunakan untuk mengetahui / menganalisa tingkat kecerahan antosianin. Pengukuran \%berat rendemen pigmen antosianin dilakukan dengan menggunakan rumus rendemen antosianin di bawah ini.

Rendemen Antosianin $=\frac{\text { Berat Ekstrak Pekat }}{\text { Berat Sampel }} \times 100 \%$

\section{Hasil dan Pembahasan}

Hasil penelitian yang diperoleh mencakup tentang hubungan antara jenis pelarut, rasio pelarut dan lama ekstraksi terhadap nilai rendemen, nilai $\mathrm{pH}$ dan nilai absorbansi dari pigmen antosianin.

Jenis pelarut, rasio pelarut dan lama ekstraksi terhadap nilai $\mathrm{pH}$ antosianin

Berdasarkan hasil analisa diketahui bahwa terdapat interaksi sangat nyata antara lama ekstraksi dan rasio pelarut (volume pelarut) terhadap nilai $\mathrm{pH}$ pigmen antosianin pada berbagai jenis pelarut yaitu campuran campuran qauades ditambah asam sitrat $10 \%$, campuran etil asetat ditambah asam sitrat $10 \%$ dan campuran etanol $95 \%$ ditambah asam sitrat $10 \%$.

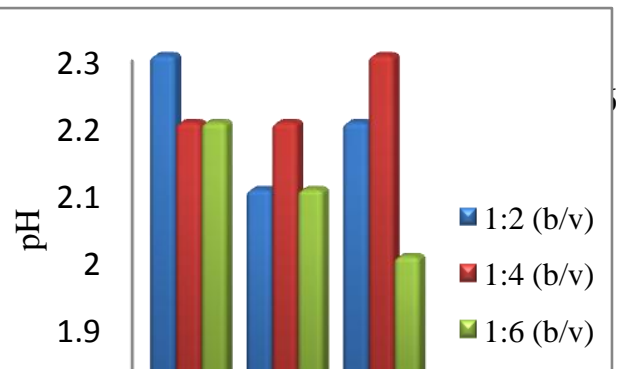


Gambar 2. Pengaruh Lama Ekstraksi dan Rasio Pelarut Terhadap pH Pada Jenis Pelarut Aquades ditambah As.Sitrat 10\%.

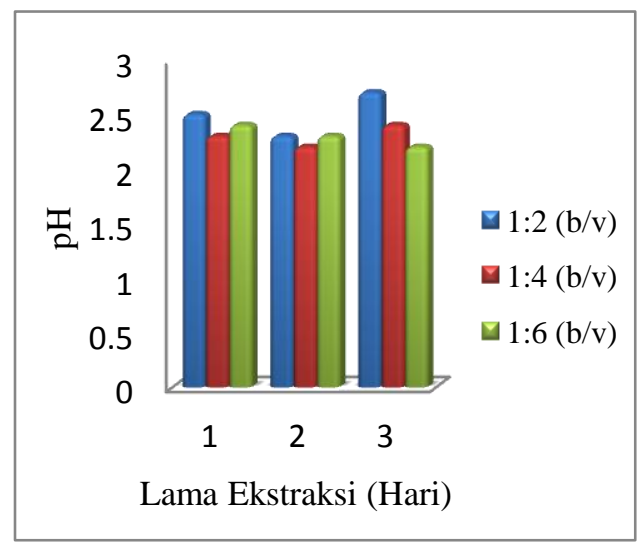

Gambar 3. Pengaruh Lama Ekstraksi dan Rasio Pelarut Terhadap pH Pada Jenis Pelarut Etanol ditambah As.Sitrat 10\%.

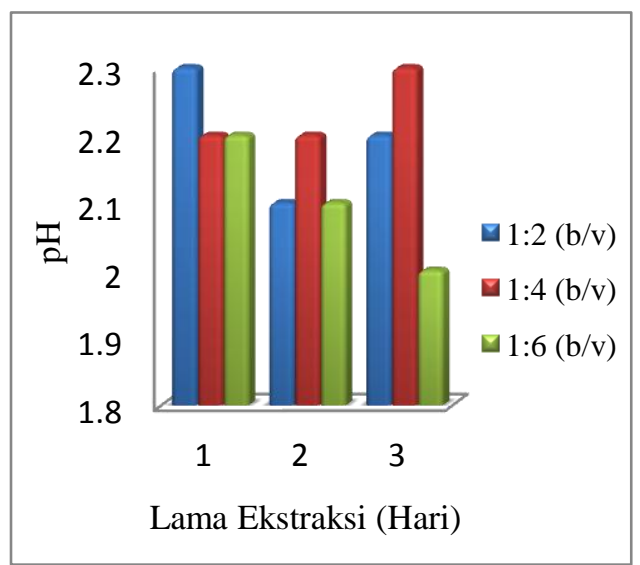

Gambar 4. Pengaruh Lama Ekstraksi dan Rasio Pelarut Terhadap pH Pada Jenis Pelarut Etil Asetat ditambah As.Sitrat 10\%.

Dari gambar 2, 3 dan 4 diatas didapat nilai $\mathrm{pH}$ yang lebih baik adalah pada campuran pelarut aquades ditambah asam sitrat dengan rasio 1:6 $(600 \mathrm{ml})$ dan lama ekstraksi 3 hari yaitu 2. Aquades merupakan larutan netral yang dapat melarutkan pigmen antosianin ditambah lagi dengan penambahan asam sitrat yang mampu menurunkan pH larutan. Keadaan yang semakin asam apalagi mendekati pH 1 akan menyebabkan semakin banyaknya pigmen antosianin berada dalam bentuk kation flavilium atau oksonium yang berwarna dan pengukuran absorbansi akan menunjukkan jumlah antosianin yang semakin besar. Disamping itu keadaan yang semakin asam menyebabkan semakin banyak dinding sel vakuola yang pecah sehingga pigmen antosianin semakin banyak yang terekstrak [4]. Sifat pigmen antosianin umumnya bersifat asam dan lebih stabil dalam kondisi asam.

Lama ekstraksi juga berpengaruh terhadap nilai $\mathrm{pH}$ pigmen antosianin. Karena semakin lama ekstraksi maka nilai $\mathrm{pH}$ semakin kecil ada pada perbandingan rasio 1:6 dengan lama ekstraksi 3 hari. Penurunan terjadi akibat bertambahnya antosianin yang terdegradasi yang menyebabkan nilai $\mathrm{pH}$ menurun.

Jenis pelarut, rasio pelarut dan lama ekstraksi terhadap nilai absorbansi antosianin

Berdasarkan hasil analisa diketahui bahwa terdapat interaksi sangat nyata antara lama ekstraksi dan rasio pelarut (volume pelarut) terhadap nilai absorbansi pigmen antosianin pada berbagai jenis pelarut yaitu campuran qauades ditambah asam sitrat $10 \%$, campuran etil asetat ditambah asam sitrat $10 \%$ dan campuran etanol $95 \%$ ditambah asam sitrat $10 \%$.

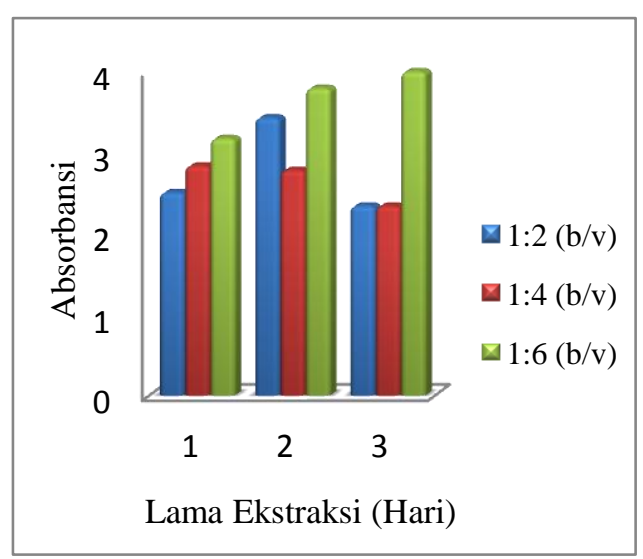

Gambar 5. Pengaruh Lama Ekstraksi dan Rasio Pelarut Terhadap Absorbansi Pada Jenis Pelarut Aquades ditambah As.Sitrat $10 \%$.

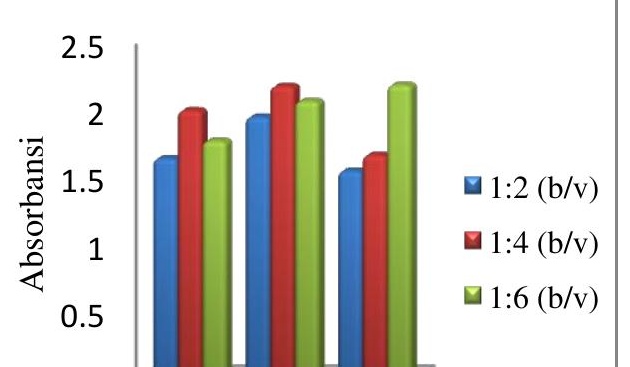


Gambar 6. Pengaruh Lama Ekstraksi dan Rasio Pelarut Terhadap Absorbansi Pada Jenis Pelarut Etanol ditambah As.Sitrat $10 \%$.

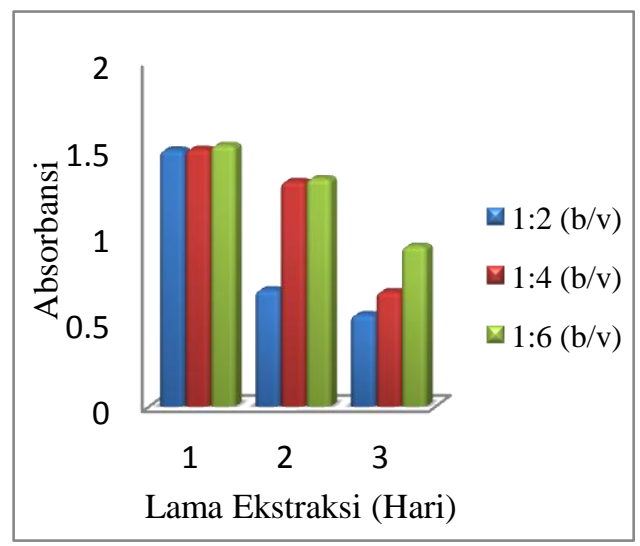

Gambar 7. Pengaruh Lama Ekstraksi dan Rasio Pelarut Terhadap Absorbansi Pada Jenis Pelarut Etil Asetat ditambah As.Sitrat $10 \%$.

Dari gambar 5, 6 dan 7 diatas maka didapat untuk nilai absorbansi yang lebih baik adalah pada jenis pelarut aquades ditambah asam sitrat, dengan perbandingan rasio 1:6 $(600 \mathrm{ml})$ dan lama ekstraksi 3 hari yaitu sebesar 4.000. Hal ini dikarenakan semakin besar nilai absorbansi maka kecerahan warnanya pun akan semakin tinggi. Fungsi pelarut untuk ekstraksi antosianin merupakan faktor yang menentukan kualitas dari suatu ekstraksi [4]. Pelarut air dan asam sitrat cocok untuk ekstraksi pigmen antosianin karena pigmen tersebut memang mempunyai sifat larut dalam air dan stabil pada kondisi asam [3].

Jenis pelarut, rasio pelarut dan lama ekstraksi terhadap rendemen Antosianin

Berdasarkan hasil analisa diketahui bahwa terdapat interaksi sangat nyata antara lama ekstraksi dan rasio pelarut (volume pelarut) terhadap nilai rendemen pigmen antosianin pada berbagai jenis pelarut.

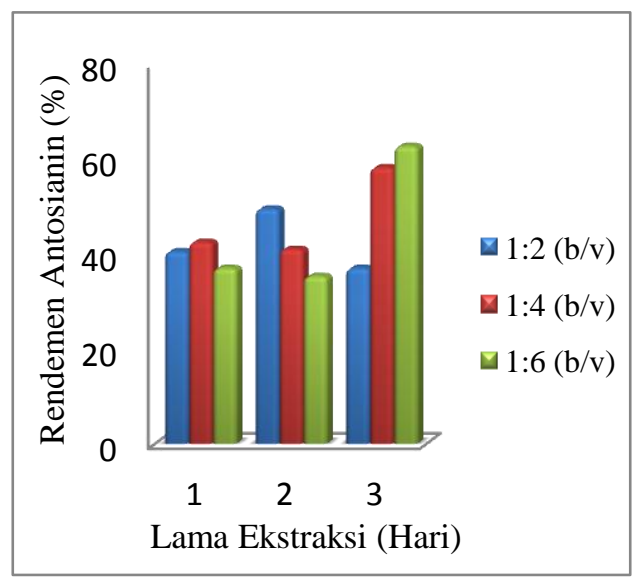

Gambar 8. Pengaruh Lama Ekstraksi dan Rasio Pelarut Terhadap Rendemen Antosianin Pada Jenis Pelarut Aquades ditambah As.Sitrat 10\%.

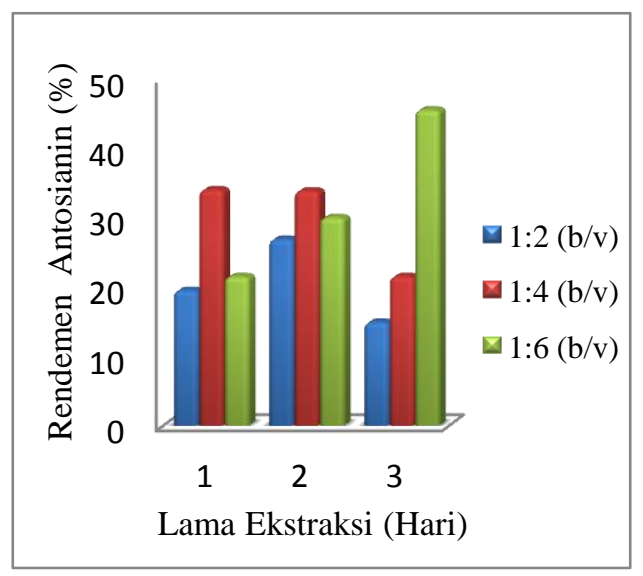

Gambar 9. Pengaruh Lama Ekstraksi dan Rasio Pelarut Terhadap Rendemen Antosianin Pada Jenis Pelarut Etanol ditambah As.Sitrat $10 \%$.

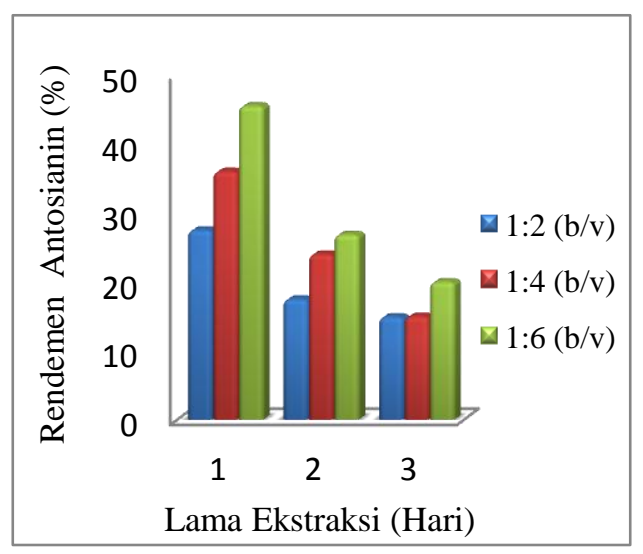

Gambar 10. Pengaruh Lama Ekstraksi dan Rasio Pelarut Terhadap Rendemen Antosianin Pada Jenis Pelarut Etil Asetat + As,Sitrat $10 \%$. Dari gambar 8, 9 dan 10 diatas maka didapatlah untuk nilai rendemen yang paling tinggi adalah pada jenis pelarut aquades 
ditambah asam sitrat, dengan perbandingan rasio 1:6 (600 ml) dan lama ekstraksi 3 hari yaitu sebesar $62,68 \%$ (\% berat). hal ini dikarenakan senyawa antosianun pada buah naga merah memiliki tingkat kepolaran yang hampir sama dengan dengan air dan alcohol. Rendemen zat warna antosianin yang berbeda pada setiap perlakuan karena kepolaran dari masing-masing pelarut yang digunakan. Zat warna antosianin merupakan senyawa polar maka akan larut baik di dalam pelarut-pelarut yang bersifat polar. Selain itu kemurnian pelarut yang digunakan mempengaruhi daya ekstraksi atau melarutnya zat warna antosianin yang terlarut didalam pelarut, sehingga akan mempengaruhi rendemen zat warna yang dihasilkan [2].

\section{Kesimpulan}

Dari hasil penelitian didapat jenis pelarut yang paling baik adalah campuran aquades dan asam sitrat $10 \%$ dengan rasio 1:6 (600 ml) dan lama ekstraksi 3 hari. Nilai Rndemen 62,68\%; nilai pH 2 dan lama ekstraksi 3 hari.

\section{Daftar Pustaka}

[1] Anis, E, Identifikasi Dan Uji Kualitas Pigmen Kulit Buah Naga Merah (Hylocareus costaricensis) Pada Beberapa Umur Simpan Dengan Perbedaan Jenis Pelarut, Jurnal Gamma, Universitas Muhamadiyah, Malang Vol 6, 2002.

[2] Harborne, J. B, Metode Fitokimia Penuntun Cara Modern Menganalisa Tumbuhan, Diterjemahkan oleh Keokasih Padmawinata, Penerbit ITB, Bandung, 1987.

[3] Jackman, R. L. dan Smith J. L, Anthocyanins and Betalains. Di dalam Hendry G. A. P dan J.D. Houghton (Eds). Natural Food Colorants, $2^{\text {nd }}$ Edition. Chapman and Hall, London, 1996.

[4] Moulana, R, Efektivitas Penggunaan Jenis Pelarut dan Asam dalam Proses Ekstraksi Pigmen Antosianin Kelopak Bungan Rosella, Jurnal Forum Teknik , Universitas Syah Kuala, Darussalam, Banda Aceh, Vol 4, No 3, 2012.

[5] Nursaerah, R, Mempelajari Ekstraksi Antosianin dari Kulit Buah Manggis (Garcinia mangostana L.) Dengan Berbagai Jenis Pelaru, Skripsi, Fakultas Teknologi Pangan Universitas Pasundan, Bandung, 2010.
[6] Tensiska, dkk., Ekstraksi Pewarna Dari Buah Arben dan Aplikasinya dalam Sistem Pangan, Jurnal Teknologi Pangan Fakultas Pertanian, UNPAD, Vol 6, 2006.

[7] Winarno, F.G, Kimia Pangan Dan Giz, PT. Gramedia Pustaka Utama, Jakarta, 1992. 